\title{
Does the Development of Alternative Energy Technologies Allow for New Forms of Coopetition?
}

\author{
Ante Galich', Lutz Marz ${ }^{2}$ \\ ${ }^{1}$ Université du Luxembourg, Faculty of Languages and Literature, Humanities, Arts and Education, Route de Diekirch \\ (B.P.2), L-7201 Walferdange, Luxembourg, ante.galich@uni.lu \\ ${ }^{2}$ Social Science Research Center Berlin, Reichpietschufer 50, 10785 Berlin, Germany
}

\begin{abstract}
The article at hand illustrates how new types of coopetition emerge in the transformation of large technical systems. It builds on the latest literature on coopetition and highlights diverse institutional arrangements for coopetition, their effects on the actual innovation and the potential benefits for the firms involved. In contrast to many incremental innovations, the transformation of large technical systems requires the cooperation of many diverse actors as various resources are needed. This does not only open up the opportunity of new private-private or public-private cooperations but also brings about various new forms of commonly performed practices.
\end{abstract}

Key words: hydrogen and fuel cells, coopetition

\section{Introduction}

Despite the common understanding that competition among private enterprises fosters productivity and innovation, it is also widely acknowledged that cooperation and competition among one and the same companies do not have to exclude each other. This hybrid and at first glance contradictory type of relationship among firms has often been termed coopetition and constitutes the subject of inquiry of a specific strand of research. Although not all studies in this field employ the term coopetition, they all share the attempt to shed light on 3 key issues of the nature of cooperation among competing firms.

First, several studies have investigated where exactly to draw the line between competition and cooperation. Bengtsson and Kock have for instance argued that simultaneous cooperation and competition between two firms can only be maintained when the firms internalize these conflictive positions and distribute the responsibilities for cooperative and competitive actions among diverse persons (Bengtsson \& Kock, 2000, p. 423). Hence, the separation of business unit matters as competitors can compete with each other in one market segment and cooperate in another one if different business units serve those segments (Bengtsson \& Kock, 2000, p. 420). Furthermore, it matters whether a product is still at the stage of development or already available at the market as competitors tend to cooperate in research and development activities that are far away from the customer, while they compete with each other in the launch of new products at the market (Bengtsson \& Kock, 2000, p. 418, 424). Dagnino and Padula have specified the intersection between competition and cooperation further and distinguish among three levels of coopetition. On the macro level firms and clusters of firms across industries compete on government research and development spending/funds, access to capital markets and shareholders investments, and activity diversification when entering new markets, while they cooperate on best practice, technology transfer, new market exploration and exploitation. One the meso level firms within an industry compete on product and factor markets, while they cooperate in product design, manufacturing, distribution and the definition of new standards. Finally, Dagnino and Padula also speak of coopetion at the micro level that is to say among functions and divisions and workers within firms. They argue that firms units compete for corporate intrafirm fund allocation, while they cooperate in product and workforce development and interchange (Dagnino \& Padula, 2002, p. 19, 20).

A second key objective of the investigations on cooperation among competing firms has been to determine the specific conditions under which coopetition takes place and their impact on a firms innovativeness. While Bengtsson \& Kock for example restricted coopetition to the relations among two firms (Bengtsson \& Kock, 2000, p. 412), Dagnino and Padula

Received: $5^{\text {th }}$ October 2011; revised $12^{\text {th }}$ December 2011; accepted $26^{\text {th }}$ February 2012 
distinguished between coopetition among diverse units within a firm, coopetion among firms and coopetition among clusters of firms (Dagnino \& Padula, 2002, p. 19, 20). Provan et al. add that the nature of the relationship among the cooperating firms varies from rather loose to more tight, but that it is generally characterized by durability and several interactions over time (Provan et al., 2007). Gilsing, Lemmens and Duysters have been more specific in this respect and have underlined the importance of a firm's strategy for the formation of networks and coopetitive relationships. Firms with an interest in exploring new business opportunities are in search of novel information and hence open towards new partners, while firms interested in the optimization of a given product will rather seek to stabilize their existing contacts (Gilsing, Lemmens \& Duysters, 2007, p. 236-239). Schilling and Phelps shed light on the role of the structure of a network and found that dense networks characterized by many ties among the individual participating organizations enable high information transmission capacity and high quantity and diversity of information and in this way foster the innovativeness of the firms involved (Schilling \& Phelps, 2007, p. 1124). This conclusion is supported by Gomez-Casseres, Hagedoorn and Jaffe that more specifically found that the exchange of knowledge within a network is greatest among firms whose relation is characterized by technological, market and geographical proximity (Gomes-Casseres, Hagedoorn \& Jaffe, 2006, p. 27). However, Bell argued that informal ties among managers have a higher impact on the innovativeness of a firm than formal relations among firms (Bell, 2005, p. 292).

Finally, various studies aim at illustrating the benefits of coopetition for individual firms. Peng et al. (2011) highlight that coopetition can lead to higher performance levels of the firms involved. Furthermore, the accumulation of knowledge through coopetition appears to be widely recognized in the literature as an added value for individual firms (e.g. Bell, 2005; Gomes-Casseres, Hagedoorn \& Jaffe, 2006; Sroka, 2010). Gilsing, Lemmens and Duysters argue further that not only the access to novel information but also the prospect of reducing the costs and the time required for the development of new technologies has led to a competition for cooperation that is to say firms compete with each other for resourceful partners (Gilsing, Lemmens \& Duysters, 2007, p. 227, 228, 233). However, it must not be forgotten that mere profit seeking behaviour may also be counterproductive. Sroka stresses this point and argues that the exchange of resources among firms requires at least a minimum level of mutual trust in order to avoid opportunistic behaviour (Sroka, 2011). Ritala and Hurmelinna-Laukkanen (2009) underline that successful coopetition depends upon the feasibility of the collective development of an innovation and the individual exploitation of it. Thus, whether firms can profit from coopetition depends not only upon their own behaviour but also upon external factors such as concrete market and technological conditions around the innovation. Innovations with a high level of novelty can open up diverse new ways of exploitation and allow for a variety of actors to identify appropriate market segments for themselves.

Our aim is to contribute to these findings of the research on coopetition by an empirical investigation of the develop- ment of hydrogen and fuel cell technologies. The development of alternative energy technologies is driven by various forces that push toward innovation. More specifically, the deployment of novel energy technologies in transport applications is driven by the availability and the price of fossil energy sources, the huge societal relevance of the automobile and the emissions caused by the transport sector and their consequences (Dierkes, Marz \& Aigle, 2009, p. 326-330). In other words, mainting our current level of mobility while simultaneously mitigating its negative consequences such as air polution and climate change requires the development and deployment of alternative energy technologies in the transport sector. These have to be compatible with renewable energy sources as the essence of the socalled »new industrial revolution « (BMU, 2008) that is to transform the energy system in the $21^{\text {st }}$ century is the shift in the energy-technology paradigm away from fossil energy technologies to renewable ones (WBGU, 2003). Due to these driving forces enterprises invest in the development of hydrogen and fuel cells and various other alternative energy technologies as both doing nothing and betting on the wrong horse could mean to fall behind in the new industrial revolution. Both could result in the disappearence of a company owing to the fundamental shift in the energy-technology paradigm outlined above.

This article sets out to investigate what impact this great transition has on the relationship among the companies involved. Our central research question is: Does the development of alternative energy technologies allow for new forms of coopetition? For this purpose we track the development of hydrogen and fuel cell technologies in the USA, the European Union and in Germany in the years from 2000-2010. In order to provide the reader with a better understanding of our study, chapter two constitutes a brief summary of the technical aspects and the history of hydrogen and fuel cell technologies. In chapter three, we first rather descriptively outline novel organizational patterns of cooperation in this field, before we proceed we a thorough analysis of the specific nature of these new forms of cooperation, their effects on the firms innovativeness and the potential benefits for individual firms involved. As both authors have a background in Science and Technology Studies, our primary aim is to explore how the literature on coopetition can be enriched by an investigation of the opportunities and requirements that the specific characteristics of the transformation of large technical systems (e.g. Hughes, 1993; Hughes \& Mayntz, 1988) feature for the cooperation among competing firms. The main conclusions drawn are summerized in chapter four of this article. Our results were obtained from a rich pool of data generated in various research projects through more than 30 in-depth interviews, direct observations and document analyses.

\section{Background}

Hydrogen and fuel cell technologies are among the most promising new energy technologies. Their linkage provides the opportunity to deploy renewable energy sources in transportation and electricity and heat generation in $\mathrm{CO}_{2}$-free energy cycles. Therefore, they target an area currently responsible 
for half of the EU's total greenhouse gas emissions (van Vliet et al., 2011, p. 248). However, whether hydrogen and fuel cell technologies actually offer the opportunity to tackle climate change and other policy issues such as the independence from the import of primary energy sources is highly contested. Some see them as key technologies of a new economic revolution that will sustainably change the world (cf. Rifkin, 2003) as they provide the opportunity to lower $\mathrm{CO}_{2}$ emissions and to reduce modern economies' dependency on crude oil. They can deliver heat and electricity for a wide range of applications from mobile phones to vehicles and industrial buildings. Others, however, deny this potential and argue that hydrogen and fuel cell technologies can neither solve energy supply problems nor contribute to a sustainable energy system (cf. Bossel, 2006; Asendorpf, 2004). Hence it is contested whether or not hydrogen and fuel cell technologies have a potential value and their development has had its ups and downs during the past two centuries.

The basic inventions of hydrogen and fuel cell technologies (hydrogen combustion engine and fuel cell) were made at the beginning of the $19^{\text {th }}$ century and today are closer to commercialization than ever before. But the history of hydrogen and fuel cell technologies clarifies very well that commercialization is no linear process. Their development for the transport sector is illustrated in detail on the website "H2Mobility" of TÜV-SÜD (TÜV-SÜD, 2010), the technical inspectorate for vehicles in Southern Germany, and is briefly summarized in the following.

The first hydrogen driven combustion engine was constructed by Issac de Rivaz in 1806. The invention did not receive much attention in the societal discourse for the next 50 years and it was not until 1863 that the next vehicle driven by a hydrogen powered combustion engine was constructed by Étienne Lenoir. Nevertheless, the technology again disappeared from the scene until the late 1920s when Rudolf Erren constructed a hydrogen-powered two-stroke engine. This development was followed by single concept studies during the following decades but none of them passed beyond the laboratory stage.

The history of fuel cell development is characterized by a similar trajectory. The mechanisms of fuel cell technologies were discovered in 1838 by the German-Swiss chemist Christian Friedrich Schönbein and the British lawyer and natural scientist Sir William Grove, who conducted research independently from one another. The fuel cell gained its actual name in 1889 from Ludwig Mond and Charles Langer who conducted thorough investigations on this technology. Still, it was not until 1932, that the first model of an alkali electrolyte fuel cell was constructed by Francis Thomas Bacon. This development was followed by the construction of the first vehicle with fuel cell propulsion in 1959.

The dynamics of hydrogen powered combustion engines and fuel cell propulsion systems present a similar picture until the late 1960s. Both developments began with basic inventions by a single person, followed by single inventions and wide temporal intervals during which the technologies did not gain any public attention. However, from the end of the 1960s, the initiatives aiming at the commercialization of hydrogen and fuel cell technologies started to increase all over the world and became even stronger at the end of the $20^{\text {th }}$ century. Automotive manufacturers such as BMW, Mazda and MAN intensified their efforts in the development of hydrogen combustion engines so that several vehicle prototypes were constructed and tested in large demonstration projects. Simultaneously, various enterprises such as Ballard, Daimler, Toyota, General Motors, Honda, and Ford worked on the development of fuel cells as propulsion systems for vehicles. Diverse car and bus prototypes with fuel cell propulsion were constructed and tested in demonstration projects.

This dramatic rise in efforts towards the commercialization of hydrogen and fuel cell technologies at the beginning of the $21^{\text {st }}$ century constitutes the point of departure of this article as it is characterized by the emergence of various networks and amalgamations among diverse enterprises within and across industries.

\section{Results}

Due to the potential of hydrogen and fuel cell technologies to tackle key issues in energy policy the networks and alliances promoting these technologies are not limited to private companies but also attract public actors such as state ministries and research institutes. In a first step, the partnerships launched in the USA, the European Union and in Germany will be illustrated rather descriptively in the following subchapter. Subsequently, we will analyze the specific nature of these novel forms of coopetition in subchapter 3.2. In particular, we focus on the concrete actions of the cooperating partners in order to determine where cooperation is possible and where it ends. Furthermore, we describe what business units are involved in coopetition and how the overall network structure relates to the activities performed. Finally, we outline the motivations for coopetition and the benefits of coopetition from the perspective of individual firms in subchapter 3.3.

\subsection{Cooperation in the promotion of hydrogen and fuel cell technologies}

In the USA, the beginning of 2001 constitutes the point of departure, as then the "National $\boldsymbol{E}$ nergy $\boldsymbol{P}$ olicy $\boldsymbol{D}$ evelopment Group" (NEPDG) was launched (NEPDG, 2001, pp. v, viii). It was composed of high-ranking US-politicians such as the then Vice-president Dick Cheney and the Secretary of State Colin Powell (ibid. p. vi). On behalf of the then President George W. Bush, its aim was to develop a long-term energy policy for the USA leading to the fulfillment of three basic goals: reliability, profitability and environmental friendliness (ibid. p. viii). The NEPDG accomplished its task with the submission of the "National Energy Policy Report" in May 2001 (ibid. v) that presents hydrogen and fuel cell technologies as one among other promising technologies of the future. In the same year, only 6 months after the submission of the report, the "National Hydrogen Vision Meeting" was convened in Washington. More than 40 representatives of energy supplying companies, environmental organizations and US-Federal and State Departments gathered in order to develop a common vision 
of a future hydrogen economy, to identify its time frame and the required interim steps towards its realization (DOE, 2001, p. iii). The US Department of Energy (hereinafter DOE), the car manufacturers Daimler, Ford and General Motors as well as the energy providers ExxonMobil and BP were among the participants (ibid. p. 24). The shared vision of a hydrogen economy which was developed on the basis of this discussion was published by the US Department of Energy in its report "A National Vision of America's Transition to a Hydrogen Economy - To 2030 and Beyond" (DOE, 2002). In 2006, the same car manufacturers and energy supplying enterprises together with the DOE formalized their collaboration further and launched the private-public partnership FreedomCAR and Fuel Partnership in order to coordinate the common activities in the development of hydrogen and fuel cell technologies (FCFP, 2006, p. iii).

In the European Union, the launch of a High Level Group by the European Commission in 2002 marks the origin of the common European institutional development of hydrogen and fuel cell technologies (EC, 2002). The High Level Group was comprised of 19 representatives from scientific institutes, industry and public administration (HLG, 2003, p. 5). The research center Jülich, the car manufacturers Daimler, Renault and Rolls-Royce, the energy providers Norsk Hydro, Shell and Sydkraft, as well as the fuel cell producer Ballard, were among them (ibid. p. 32). In 2003, the High Level Group published the report "Hydrogen Energy and Fuel Cells. A vision of our future" (HLG, 2003) that outlines the vision of a hydrogen-based economy established by 2050. On the basis of this report, the European Commission set up the "European $\boldsymbol{H y d r o g e n}$ and $\boldsymbol{F}$ uel Cell Technology Platform" in the same year (HFP) (EC, 2004) which subsequently developed a European research (HFP, 2005a) and deployment (HFP, 2005b) agenda to exemplify the commercialization process of hydrogen and fuel cell technologies. The majority of the High Level Group members (HLG, 2003, p. 32) took over high-ranking positions in the Executive Group (HFP, 2004a, p. 1) and in the Advisory Council (HFP, 2004b) of the HFP. Building on the initiatives of the HFP, the European Council set up a subsequent agency, the "Fuel $\boldsymbol{C}$ ell and $\boldsymbol{H}$ ydrogen Joint Undertaking" (hereinafter FCH JU), on May, 30 ${ }^{\text {th }} 2008$ which constitutes a legal body launched under Belgian law in Brussels (Council of the European Union, 2008, pp. 1, 4; FCH JU, 2009, p. 4). It is characterized by a complex organizational structure composed of representatives from industry, science, the European Commission and the European Union member states (FCH JU, 2009, pp. 23, 24). Again, there is an overlap with the HFP whose staff at least partly moved on into the FCH JU (HFP, 2004a, p. 1; HFP, 2004b; FCH JU, 2010).

In Germany, three agencies have been of particular importance for the promotion of hydrogen and fuel cell technologies during the past decade: the "Transport $\boldsymbol{E}$ nergy $\boldsymbol{S}$ trategy" (hereinafter TES), the "Clean Energy Partnership" (hereinafter CEP) and the "National Organization Hydrogen and Fuel Cell Technology" (hereinafter NOW). The TES was established by the Federal Government, the original equipment manufacturers (hereinafter OEM) BMW, Daimler, MAN and VW from the automobile sector and the energy suppliers ARAL, RWE and Shell in May 1998 (TES, 2000, p. 3). Later on, it was joined by Ford, GM/Opel, Total and Vattenfall. The launch of the CEP (Clean Energy Partnership) was already suggested in the second status report of the TES in June 2001 (TES, 2001, p. 5), before the CEP was officially set up in October 2003. The CEP is composed of car manufacturers, energy suppliers and end users such as Aral, BMW, BVG, Daimler, Ford, GM/Opel, Hamburger Hochbahn, Linde, StatoilHydro, Total, Vattenfall and Volkswagen which gathered in order to perform demonstration projects. The Federal Government is represented by the Federal Ministry of Transport, Building and Urban Development. Finally, the National Organization Hydrogen and Fuel Cell Technology (NOW) was set up in 2008 as the central and overarching institution equipped with its own budget to fund all activities concerning hydrogen and fuel cell technologies in Germany such as the demonstration projects performed by the CEP. In legal terms, the NOW is a limited liability company $(\mathrm{GmbH}) 100 \%$ owned by the Federal Government and represented by the Federal Ministry of Transport, Building and Urban Development (NOW, 2011). The NOW has a supervisory board composed of the representatives of the four Federal Ministries involved and an advisory board that also includes representatives from the industry and public research institutes.

This brief overview indicates that actors from diverse societal areas such as politics, industry and science gathered in order to promote hydrogen and fuel cell technologies in common. The key actors from the industry are OEMs from the automobile sector and mineral oil companies. The specific nature of their cooperation will be portrayed more in detail in the following subchapter.

\subsection{Novel types of coopetition and their effects on the development of innovations}

As the previous subchapter revealed, the cooperative networks are composed of representatives from various ministries and public research institutes. But also private companies within and across certain industries are involved. These enterprises usually have their experts whose task is to represent the companies' activities in alternative technologies and to mobilize political, financial and partly also public support for these activities. Typically, they have a background in engineering or business studies. However, these persons do not belong to the public relations divisions of the companies but rather should be conceived as specialists that thoroughly follow the technological development and research in their own company and represent their companies in the cooperative partnerships. They can be regarded as the key actors in coopetitive relationships among firms as they control the flow of information between their company and the broader technical community and hence they constitute the interface among the diverse companies. This crucial position enables them to perform five practices of coopetition which are to be explained in the following paragraphs: (1) networking, (2) agency creation, (3) agenda setting, (4) problem/solution framing, and (5) vision building.

Networking. Networking refers to the management of existing relations to other companies or public organization 
and to the establishment of new ties. This can be done at conferences, workshops or at other official meetings where representatives from various organizations meet in order to exchange views on hydrogen and fuel cells and other alternative technologies. The so-called parliamentary evenings which are held on a regular basis are of particular importance as they provide diverse actors from politics, science and industry with the opportunity to meet and to inform each other about the latest developments in hydrogen and fuel cell technologies (Fuel Cell Alliance, 2006). Thus networking can be conceived as a more informal practice that aims at the exchange of information without obligation.

Agency creation. However, successful networking can result in the formalization of certain relationships. The practice of agency creation refers to the launch of official institutions. Hence agency creation is characterized by more commitment of the persons involved and requires an agreement upon the stage of development in a technology and it's potential. This consensus might be as thin as a general commitment to the promising potential of hydrogen and fuel cells and an agreement on the need of further research in these technologies. But as the agencies launched are often equipped with their own budget contributed by all private and public organizations involved, there usually exists a more concrete roadmap for the further proceeding that clarifies the direction of research and the objectives for the years coming. In the development of hydrogen and fuel cell technologies in Germany, the launch of the NOW constitutes a prime example for the creation of an agency. The NOW was implemented on the initiative of other agencies such as the TES and the CEP in order to set up a superordinate authority that would eventually merge all of them into one central organization. The main task of the NOW is to coordinate and steer all demonstration projects in order to push hydrogen and fuel cell technologies towards market entry (NOW, 2010).

Agenda setting. The launch of the NOW was preceded by other practices that established a common view of hydrogen and fuel cell technologies which allowed the allocation of financial resources and common investments. The practice of agenda setting can, for instance, result in agency creation but can also result from it. Agenda setting focuses on the development, promotion and implementation of strategies, programs or plans for the commercialization of certain technologies. In Germany, the TES deployed agenda setting most successfully as it, for example, suggested the launch of the CEP in June 2001 (TES, 2001, p. 5) and the CEP was set up in October 2003 (CEP, 2007, p. 3). The TES has also lobbied towards the establishment of a European institution for the development of hydrogen and fuel cell technologies and has apparently succeeded as the launch of the Fuel Cell and Hydrogen Joint Undertaking by the Council of the European Union indicates (Council of the European Union, 2008, p. 1). Finally, the TES had been successfully lobbying towards the development of a national innovation program for hydrogen and fuel cell technologies as such a program was initiated by three Federal Ministries in 2006 (BMVBS et al., 2006).

Problem/solution framing. However, agenda setting can not only precede agency creation but also results from it as the NOW after its launch became the key actor that determines the further development of hydrogen and fuel cell technologies in Germany. The same can be said for the two practices of problem/solution framing and vision building which clarifies that all practices do not have to be performed in a specific order but rather should be conceived of as overlapping and simultaneous. Problem/solution framing aims at portraying hydrogen and fuel cell technologies as a feasible solution to serious problems of modern societies. Consequently, the practice always starts with the presentation of a certain problem as, for example, climate change, rising oil prices, transport sector emissions or the dependency of Western economies on the import of crude oil. All these issues are portrayed as urgent problems that endanger our standard of living which then allows to present hydrogen and fuel cell technologies as the ideal solutions that enable an emission-free energy and transport sector on the basis of renewable energies (cf. BMW, 2008, p. 33; CEP, 2009, p. 5, 8, 9-12; NOW, 2009, p. 1).

Vision building. In contrast to problem/solution framing the practice of vision building does not focus on current problems but rather highlights the potential of hydrogen and fuel cell technologies by future visions. Vision building means embedding hydrogen and fuel cell technologies in a future world that reflects the current desires for a sustainable and secure energy system. Successful vision building can bring together various actors and coordinate their further actions as they all pursue the same target of realizing the vision. In this way, vision building contributed to networking and agency creation in particular in the USA and the EU and partly also in Germany (Marz and Krstacic-Galic, 2010, p. 15 25). However, it should be noted that the level of commitment in vision building can vary considerably as countless hydrogen visions have been developed but only few gained actual importance in the sense that several actors accepted them as desirable targets.

This illustrates that the effects of the five practices of coopetition on the development of innovations depend not only on the commitment of the actors to certain practices, but also on the combination and the mutual reinforcement of the individual practices. Successful networking, agenda setting, problem/solution framing and vision building can foster close cooperation and mutual trust and pave the way towards the creation of a central agency that is well equipped with financial resources. This in turn can strengthen the ties among the partners involved and lay a more solid foundation for further networking, agenda setting, problem/solution framing and vision building. In Germany, for instance, networking, agenda setting and problem/solution framing resulted in the launch of the NOW which enables even closer networking and cooperation through funded demonstration projects. In the EU and in the USA, however, problem/solution framing and vision building paved the way for networking and eventually for agency creation. Apparently, at least two practices of coopetition need to be applied successfully in order to have a significant impact on innovation. This impact can range from the exchange of information that can lead to an accelerated internal development of innovations to the alignment of interests and objectives that result in common investments and demonstration projects.

Although the applications of hydrogen and fuel cell technologies are not available on the market, yet, this does 
not mean that cooperation is omnipresent while competition does not exist. Of course, following Bengtsson and Kock (Bengtsson \& Kock, 2000, p. 418, 424) in general it can be assumed that competition will increase as hydrogen and fuel cell technologies move closer towards commercialization. But a thorough look at the empirical data reveals that cooperation and competition take place simultaneously already at this early stage of development in hydrogen and fuel cell technologies. Thus, our results build on the findings of Gilsing, Lemmens \& Duysters who identified a competition for resourceful partners (Gilsing, Lemmens \& Duysters, 2007, p. 227, 228, 233). Small and medium size enterprises (hereinafter SME), for instance, compete with each other for resourceful, large partners within and across industries.

Furthermore, we identified competition within and across industries for the setting of technical standards. There is, for instance, a huge schism between automotive manufacturers concerning the deployment of hydrogen as a fuel in automobile applications. While BMW worked from the 1980ies until 2008 on the optimization of the use of hydrogen in an internal combustion engine, Daimler preferred until 2008 the replacement of the internal combustion engine as propulsion system with fuel cells powered by hydrogen and has therefore cooperated with the Canadian fuel cell manufacturer Ballard. Thus both companies focused on the improvement of the internal combustion engine or the fuel cell, respectively, for a long time, but since a few years both also work increasingly on the battery technology. This example illustrates that both companies compete not only within the automotive sector, but also across industries in order to convince other actors to develop those hydrogen and fuel cell applications that suit their concept of a transport sector relying on hydrogen.

Hence, Bengtsson and Kock are not wrong in claiming that competition increases with the proximity to the market. But the development or the transformation of large technical systems requires the construction of a novel technical infrastructure which leads to competition long before the first applications are available on the market. Various actors compete for the establishment of technical standards within and across industries that suit their interests and strategies. Thus competition takes place in all practices of coopetition because diverse actors have differing conceptions of how societal problems should be solved, how a visionary future transport system should look like, what topics should be set on the agenda and what directions of research and development should be pursued by agencies. In a nutshell, the transformation of a large technical system such as the energy or the transport system is accompanied by simultaneous cooperation and competition right from the start.

\subsection{Motivations for coopetition and benefits for firms}

We have already stressed the significance of the specific circumstances of transitions of large technical systems for coopetition relationships among diverse public and private actors in the preceding subchapter. The development of an infrastructure for a transport system based on hydrogen requires the cooperation of energy supplying companies and OEMs from the automotive sector as diverse technical applications need to be developed in parallel and adjusted to each other. Often no one can predict what technological application will reach a breakthrough and, therefore, various firms cooperate in order to share risks and financial efforts in the simultaneous development of diverse technological alternatives. The issue of hydrogen storage, for instance, requires the concentrated efforts of companies from diverse industries.

Another benefit from the coopetitive relationships described above is mutual observation. One of the largest risks to individual companies in the transition of large technical systems is to miss the stabilization of a new technical system. Stabilization occurs when relevant actors from diverse technical areas agree upon the adjustment of all technical components required for the construction of the entire system. In the case of hydrogen and fuel cell technologies this could, for instance, mean that certain energy supplying companies and automobile manufacturers agree upon a specific level of pressure for compressed hydrogen so that certain technological standards become established. Consequently, energy supplying companies that worked on the development of filling stations with another level of pressure for compressed hydrogen would lose out as well as automobile manufacturers that invested in vehicle propulsion systems that require another level of pressure for compressed hydrogen. Depending on the scale of investment in the wrong direction, bankruptcy could be the result not only for small- and medium-size enterprises.

Thus mutual observation and information exchange become the biggest assets in coopetitive relationships in the transformation of large technical systems. Participation in networking, agency creation, agenda setting, problem/solution framing, and vision building enables the firms not only to keep track of the development in other companies, but also provides them with the opportunity to influence the direction of future proceedings according to their own interests. Based on the information on the strategies of other organizations involved, every firm can develop its own strategy, adjust it to other strategies and attempt to convince other actors of their concept of a sustainable mobility. Eventually, that is to say with decreasing proximity to the market, participation in practices of coopetition also means to define who is to serve what segments in the evolving market.

Another motivation for coopetition and a prime example of cooperation and competition in parallel is the quest for public funding. The launch of the NOW in Germany has illustrated that concentrated efforts of diverse private companies are required in order to define the transition towards a sustainable transport system as sort of a national mission. Cooperation among firms is needed to convince policy-makers of the necessity of an agency well equipped with public money. This partly enables cooperation among companies that actually have differing ideas of how the future transport system should look like. BMW, for instance, pursues the strategy of deploying hydrogen in a combustion engine as propulsion system for vehicles, while Daimler bets on hydrogen powered fuel cells. But both companies share an interest in public support for hydrogen which enabled them to lobby for the launch of the NOW in common. 
However, as soon as such an agency is launched and the first call for proposals for project funding is published, cooperation turns into competition among individual firms or consortia of firms with an interest in a common project. Furthermore, confirming the results of Bell (Bell, 2005, p. 288, 289), we found that a central network position accompanied by close ties to resourceful partners results in a higher likelihood to receive public funding. Hence not only the common interest to lobby for public funding can serve as a motivation for cooperation, but also the prospect of receiving a certain amount of the available funding through a central network position resulting from close cooperation with resourceful partners.

Finally, we also identified obstacles to cooperation. The most striking issue is the ubiquitous idea that the cooperation will come to an end as soon as the technology comes closer to the market that all actors involved in the practices of coopetition keep at the back of their minds. Successful cooperation results in accelerated technology development which eventually results in a market breakthrough and tough competition. This idea is present right from the start and all actors involved are very aware of the time-limited nature of their cooperation. Consequently, this idea impedes a too close cooperation from its origin to its end.

Furthermore, we found that differing conceptions of how the future transport system should look like can impede cooperation to a certain extent. The example of BMW and Daimler who pursue differing technological pathways towards a transport system based on hydrogen serves as a good illustration of this issue. The common interest in establishing hydrogen as a fuel in the transport sector enables both companies to cooperate in lobbying for public funding and in the exchange of information. However, BMW envisages deploying hydrogen in a combustion engine, while Daimler invests in fuel cells powered by hydrogen. These differing technological pathways impede a closer cooperation in, for instance, demonstration projects.

\section{Discussion}

Our analysis revealed that the transformation of large technical systems requires and brings about new types of coopetition. The NOW constitutes a prime example of these novel, hybrid institutions. It is a limited so to speak a state-owned liability company by law with an advisory board and a supervirsory board. While the supervisory board is only composed of representatives from several Federal Ministries, the advisory board also consists of representatives from private companies and public research institutions. These actors gathered together on the basis of technological requirements such as the transformation of the infrastructure of the transport sector which neither public nor private actors can accomplish on their own. They participate in such new types of coopetition not only in the hope of new market shares in the transport system transformed but also in the fear of missing key developments and lagging behind.

The actors involved in novel types of coopetition develop five specific practices in order to achieve their common objectives: networking, agency creation, agenda setting, vision building, and problem/solution framing. These practices are not performed independently from one another but rather simultaneously and combined. They are performed in various contexts such as political, economical or ecological ones. Organizations involved in the development of hydrogen and fuel cells attempt, for instance, to link these technologies to renewable energies and argue for a zero-emission and sustainable economy based on hydrogen. The deployment of the practices in specific contexts can be both stabilizing and destabilizing for the coopetition arrangement. Of course, the more all participants agree upon their future objectives in detail, the more stable their cooperation will become. However, technological development is unpredictable and progress in hydrogen and fuel cells or relating technologies might open up new opportunities so that the actors involved have to renegotiate their common objectives if they want to prevent a destabilization of their coopetition arrangement. Furthermore, of course, the stability of the coopetition arrangements decreases with increasing proximity to the market that is to say to the commercialization of hydrogen and fuel cell technologies.

Finally, it should also be noted that the specific form of coopetition in the case of hydrogen and fuel cell technologies has its flaws. The largest deficit is probably the lacking involvement of the end user in the development of these technologies (see for example Canzler \& Marz, 2011). More involvment of the end user could not only make these technologies wider know in the broader public but in the end also accelerate their commercialization by suiting them better to the needs of potential customers.

\section{References}

Bell, G. G. (2005). Clusters, Networks and Firm Innovativeness. Strategic Management Journal. 26(3), 287-295. DOI: 10.1002/ smj.448

Bengtsson, M. \& Kock, S. (2000). »Coopetition« in Business Networks - to Cooperate and Compete Simultaneously. Industrial Marketing Management. 29(5), 411-426. DOI: 10.1016/S0019-8501(99)00067-X

BMU (Federal Ministry for the Environment, Nature Conservation and Nuclear Safety). (2008). Die dritte industrielle Revolution - Aufbruch in ein ökologisches Jahrhundert. Dimensionen und Herausforderungen des industriellen und gesellschaftlichen Wandels. Berlin: German Government Publishing Service

BMVBS (Federal Ministry of Transport, Building and Urban Development), BMBF (Federal Ministry of Education and Research) \& BMWi (Federal Ministry of Economics and Technology). (2011). Nationaler Entwicklungsplan. Version 3.0 zum Innovationsprogramm Wasserstoff- und Brennstoffzellentechnologie. Berlin: German Government Publishing Service

BMW (Bayerische Motorenwerke). (2008). H2. Mobility of the Future. Retrieved December 18, 2010, Retriewed from http:// www.bmwgroup.com/bmwgroup_prod/bmw_H2_Mobilitaet_ Zukunft_gesamt_e.pdf

Bossel, U. (2006). Wasserstoff löst keine Energieprobleme. Technologiefolgenabschätzung. Theorie und Praxis. 15(1), 26-33.

Canzler, W. \& Marz, L. (2011). Wert und Verwertung neuer Technologien. Leviathan. 39(2), 223-245. DOI: 10.1007/ s11578-011-0116-z 
CEP (Clean Energy Partnership). (2007). Report 2002-2007. Berlin: Clean Energy Partnership

CEP (Clean Energy Partnership). (2009). Clean Energy Partnership. Mobil mit Wasserstoff. Berlin: Clean Energy Partnership

Council of the European Union. (2008). Regulations. Council Regulation (EC) No 521/2008 of 30 May 2008 setting up the Fuel Cells and Hydrogen Joint Undertaking. Brussels: Official Journal of the European Union

Dagnino, G. B. \& Padula, G. (2002). Coopetition Strategy. A New Kind Of Interfirm Dynamics For Value Creation. In Innovative Research in Management, 9-11 May 2002 (pp. 1-32). Stockholm

Asendorpf, D. (2004). Die Mär vom Wasserstoff. Die Zeit. (2004, October 7). pp. 1-4

Dierkes, M., Marz, L. \& Aigle, T. (2009). »Die automobile Wende. Analyse einer Innovationslandschaft«. In: R. Popp \& E. Schüll (Eds.), Zukunftsforschung und Zukunftsgestaltung. Beiträge aus Wissenschaft und Praxis (pp. 323-340). Berlin, Heidelberg: Springer

DOE (US Department of Energy). (2001). Proceedings. National Hydrogen Vision Meeting. Washington: U.S. Government Publishing Service

DOE (US Department of Energy). (2002). A National Visions Of America's Transition To A Hydrogen Economy. To 2030 And Beyond, Based on the results of the National Hydrogen Vision Meeting. Washington: U.S. Government Publishing Service

EC (European Commission). (2002). Commission to launch High Level Group on Hydrogen and Fuel Cell technologies. Retrieved August 12, 2010, from http://europa.eu/rapid/pressReleasesAction.do?reference $=\mathrm{IP} / 02 / 1282 \&$ format $=$ HTML\&aged=1\&langu age $=$ EN\&guiLanguage $=$ en

EC (European Commission). (2004). Hydrogen economy: New EU hydrogen and fuel cell Quick Start initiative, Retrieved August 14, 2010, from, http://europa.eu/rapid/pressReleasesAction.do? reference $=\mathrm{IP} / 04 / 363 \&$ format $=$ HTML $\&$ aged $=0 \&$ language $=\mathrm{EN}$ $\&$ guiLanguage $=$ en

FCFP (FreedomCAR and Fuel Partnership). (2006). Partnership Plan. FreedomCAR \& Fuel Partnership. Washington: U.S. Government Publishing Service

FCH JU (Fuel Cell and Hydrogen Joint Undertaking). (2009). Multi - Annual Implementation Plan 2008 - 2013. Brussels: Fuel Cell and Hydrogen Joint Undertaking

FCH JU (Fuel Cell and Hydrogen Joint Undertaking). 2010. Members of the FCH JU Scientific Committee. Retrieved August 11, 2010, from http://ec.europa.eu/research/fch/pdf/fch_ju_scientific_committee.pdf\#view=fit\&pagemode=none

Fuel Cell Alliance. (2006). Bericht zum parlamentarischen Abend in der Landesvertretung Niedersachsen in Berlin. Wasserstoff- und Brennstoffzellentechnologien - Deutschland quo vadis? Berlin: Fuel Cell Alliance

Gilsing, V. A., Lemmens, C. E. A. V. \& Duysters, G. (2007) Strategic Alliance Networks and Innovation: A Deterministic and Voluntaristic View Combined. Technology Analysis \& Strategic Management, 19(2), 227-249. DOI: 10.1080/09537320601168151

Gomes-Casseres, B., Hagedoorn, J. \& Jaffe, A. B. (2006). Do alliances promote knowledge flows? Journal of Financial Economics, 80(1), 5-33. DOI: 10.1016/j.jfineco.2004.08.011

HFP (Hydrogen and Fuel Cell Technology Platform). (2004a). First Meeting of the Executive Group. Brussels: Platform Secretariat. (EHP-EG 2/2004 Rev.1)

HFP (Hydrogen and Fuel Cell Technology Platform). (2004b) European Hydrogen and Fuel Cell Technology Platform. Advisory Council. Retrieved August 11, 2010, from http://circa. europa.eu/Public/irc/rtd/eurhydrofuelcellplat/library?l=/publicsarea/advisoryscouncil/acslists121203pdf/_EN_1.0_\&a=d
HFP (European Hydrogen \& Fuel Cell Technology Platform). (2005a). European Hydrogen \& Fuel Cell Technology Platform. Strategic Research Agenda. Brussels: Platform Secretariat

HFP (European Hydrogen \& Fuel Cell Technology Platform). (2005b). European Hydrogen \& Fuel Cell Technology Platform. Deployment Strategy. Brussels: Platform Secretariat

HLG (High Level Group). (2003). Hydrogen Energy and Fuel Cells. A vision of our future, Final Report of the High Level Group. Brussels: European Commission Publishing Service. (EUR $20719 \mathrm{EN})$

Hughes, T. P. (1993). Networks of Power: Electrification in Western Society, 1880-1930. Baltimore, London: The John Hopkins University Press

Hughes, T. P. \& Mayntz, R. (1988). The Development of Large Technical Systems. Frankfurt am Main: Campus Verlag

Marz, L. \& Krstacic-Galic, A. (2010). Wert-volle Visionen. Die Bedeutung von Leitbildern in Wertgebungsprozessen der Wasserstoff- und Brennstoffzellentechnologie. Discussion Paper SP III 2010-404. Berlin: Wissenschaftszentrum Berlin für Sozialforschung

NEPDG (National Energy Policy Development Group). (2001). National Energy Policy. Report of the National Energy Policy Development Group. Washington: U.S. Government Printing Office

NOW (National Organization Hydrogen and Fuel Cell Technology). (2009). Die Clean Energy Partnership. Übergeordnete Module, Nationale Organisation Wasserstoff- und Brennstoffzellentechnologie. Retrieved December 15, 2010, from http://www.now-gmbh.de/uploads/tx_goprojektfinder/ NIP_CEP_091217.pdf

NOW (National Organization Hydrogen and Fuel Cell Technology). (2010). Preparing the Market. Retrieved November 20, 2010, from http://www.now-gmbh.de/en/now/who-we-are/functions. html

NOW (Nationale Organisation Wasserstoff- und Brennstoffzellentechnologie). (2011). Homepage. Aufgaben. Retrieved February 2, 2011, from http://www.now-gmbh.de/index. php?id $=21 \& \mathrm{~L}=1111 \% 27$

Peng, T.-J. A., Pike, S., Yang, J. C.-H. \& Roos, G. (2011). Is Cooperation with Competitors a Good Idea? An Example in Practice. British Journal of Management. DOI: 10.1111/j.14678551.2011.00781.x

Provan, K.G., Fisch, A. \& Sydow, J. (2007). Interorganizational networks at the network level: a review of the empirical literature on whole networks. Journal of Management. 33(3), 479-516. DOI: $10.1177 / 0149206307302554$

Rifkin, J. (2003). The Hydrogen Economy. The Creation Of The Worldwide Energy Web And The Redistribution Of Power On Earth. The Next Great Economic Revolution. Tarcher

Ritala, P. \& Hurmelinna-Laukkanen, P. (2009). What's in it for me? Creating and appropriating value in innovation-related coopetition. Technovation. 29(12), 819-828. DOI: 10.1016/j. bbr.2011.03.031

Schilling, M. A. \& Phelps, C. C. (2007). Interfirm Collaboration Networks: The Impact of Large-Scale Network Structure on Firm Innovation. Management Science. 53(7), 1113-1126. DOI: $10.1287 / \mathrm{mnsc} .1060 .0624$

Sroka W. (2010). Alliance Networks: the Case of Multinational Corporations. Organizacija. 43(4), 165-172. DOI: 10.2478/ v10051-010-0016-z

Sroka, W. (2011). Problem of Trust in Alliance Networks. Organizacija. 44(4), 101-108. DOI: 10.2478/v10051-011-00100 
TES (Transport Energy Strategy). (2000). Statusbericht der TaskForce an das Steering-Committee. Unpublished report

TES (Transport Energy Strategy). (2001). Zweiter Statusbericht der Task-Force an das Steering-Committee. Retrieved November 30, 2010, from http://www.bmvbs.de/cae/servlet/contentblob/30514/publicationFile/1155/zwischenbericht-2001.pdf

TÜV-SÜD. (2012). Tata Starbus Fuel Cell (hydrogen) (2012). Retrieved February 19, 2012, from http://www.netinform.net/ H2/H2Mobility/Default.aspx

Van Vliet, O., van den Broek, M., Turkenburg, W. \& Faaij, A. (2011). Combining hybrid cars and synthetic fuels with electricity generation and carbon capture and storage. Energy Policy. 39(1), 248-268. DOI: 10.1016/j.enpol.2010.09.038

WBGU (German Advisory Council on Global Change). (2003). Welt im Wandel: Energiewende zur Nachhaltigkeit. Berlin, Heidelberg, New York: Springer.

Ante Galich is a doctoral candidate in political science at the University of Luxembourg, Faculty of Language and
Literature, Humanities, Arts and Education. He graduated in sociology at the University of Bielefeld and worked as a scientific assistant at the Social Science Research Center Berlin. His research interests include science and technology studies, energy policy and alternative energy technologies.

Lutz Marz is a scientific assistant at the Research Unit Cultural Sources of Newness at the Social Science Research Center Berlin. Currently, he is conducting the project valorization alliances and agencies which aim is to formulate plausible and robust hypotheses on the emergence and functioning of valorization alliances and valorization agencies in order to test these in other technical and social innovation fields. His research interests cover futurology, mobility and innovation studies, hydrogen and fuel cell technologies and epistemic communities. He has published over 50 scientific papers, articles and contributions to edited volumes. 